\title{
Stress and Burnout in Teachers During Times of Pandemic
}

\author{
Natalia Vargas Rubilar ${ }^{* *}$ and Laura Beatriz Oros² \\ ${ }^{1}$ Instituto de Educación Superior № 9-027, Universidad del Aconcagua, Mendoza, Argentina, ${ }^{2}$ Centro de Investigación en \\ Psicología y Psicopedagogía-UCA-CONICET, Universidad Adventista del Plata, Mendoza, Argentina
}

In Argentina, once mandatory isolation was declared due to the COVID-19 pandemic, teachers of all educational levels and modalities had to substantially modify their way of working. The aim of this study was to identify the work situations that education professionals perceived as threats under the modality of non-face-to-face teaching, and to describe the level of perceived stress and its possible effect on psychophysical symptoms. Likewise, it sought to examine possible differences in the manifestations of burnout depending on the level of perceived stress and associated symptoms. An empirical study with a cross-sectional design was developed, in which 9,058 Argentine teachers, who had to complete self-report measures, participated. The sampling method was non-random, using an online procedure of reclusion of volunteers. Descriptive techniques and non-parametric tests were used for data analysis. More

OPEN ACCESS

Edited by:

Gustavo Carlo,

University of Missouri, United States

Reviewed by:

Maria Clelia Zurlo,

University of Naples Federico II, Italy Kathryn Anne Nel,

University of Limpopo, South Africa

*Correspondence: Natalia Vargas Rubilar vargasnati@gmail.com

Specialty section:

This article was submitted to Health Psychology, a section of the journal Frontiers in Psychology

Received: 09 August 2021 Accepted: 08 November 2021 Published: 26 November 2021

Citation:

Vargas Rubilar $N$ and Oros $L B$ (2021) Stress and Burnout in Teachers During Times of Pandemic.

Front. Psychol. 12:756007. doi: 10.3389/fpsyg.2021.756007 than $60 \%$ of the educators reported high and moderately high levels of stress. The predominant stressors were uncertainty about the consequences of the pandemic, work overload and inadequate working environment. The more stress they perceived, the higher the manifestation of unwanted psychophysical symptoms. Professional burnout was higher for teachers with a higher load of stress and with more psychophysical indicators of discomfort. These results reveal the psychological impact of the COVID19 pandemic on the education staff, and encourage the development of intervention measures to preserve the health of professionals.

Keywords: stress, burnout, teaching, pandemic, COVID-19

\section{INTRODUCTION}

The World Health Organization declared the outbreak of the new coronavirus a pandemic on March 11, 2020, after the number of people infected and deaths from COVID-19 increased exponentially in 110 countries on different continents. Given the aggravation of the epidemiological situation at an international level, this organization urged world leaders to take immediate measures in order to face this sanitary crisis. In Argentina, the National Executive Branch established the social, preventive and mandatory isolation, starting March 20, 2020, as a measure to prevent the contagion, mitigate the circulation of the virus and preserve public health. Consequently, faceto-face classes were suspended from that date at all levels and modalities. Facing this situation, educational institutions had to quickly reorganize in order to give continuity to the academic year under the non-face-to-face modality.

After the first weeks of mandatory quarantine, several journalistic reports highlighted that education professionals throughout the country manifested feelings of distress due to the closure 
of schools, and felt overwhelmed by the dizzying change that virtual teaching implied (Carnese, 2020; Di Vincenzo, 2020; Favant, 2020; Fernández, 2020; Figueroa Díaz, 2020; Santoro, 2020; Vallejos, 2020). In the same way, studies conducted by different teachers' unions revealed that social confinement had substantially transformed the work scenario of educators. At the same time, they noticed that these changes were affecting the health of teachers of all levels (see Confederación de Trabajadores de la Educación de la República Argentina, 2020; Sindicato Argentino de Docentes Particulares, 2020; Sindicato Unificado de Trabajadores de la Educación de Buenos Aires, 2020).

Over the years, various authors have pointed out that education workers show a high risk of developing anxiety, stress and burnout as a consequence of being exposed to a wide range of work stressors in their daily activities (Esteve, 1994; Gil-Monte and Peiró, 1997; Schaufeli and Enzmann, 1998; Vandenberghe and Huberman, 1999; Manassero et al., 2003; Schaufeli, 2003; Gil-Monte, 2005; Menghi, 2015; Othman and Sivasubramaniam, 2019). In Argentina, since March of 2020, teachers have seen many aspects of their work modified. This situation could lead to an increase in the perception of work stressors and/or intensity educators attribute to those stressors, making them even more prone to those maladjustments.

The interactional model of stress, proposed by Lazarus and Folkman (1986), offers a conceptual framework that allows us to understand not only the background, but also the mediators and the possible consequences of psychological stress. According to this perspective, stress arises when the transactions with the environment are assessed as threatening. In this way, different situations and stimuli may assume the nature of stressors, as long as they are considered dangerous for the achievement or the maintenance of wellness. The greater the potential for damage perceived in the demands of the environment and the lower the ability of the individual to cope with them, the greater the negative impact of stress.

Demands are conceived as explicit or implicit pressures in the environment that lead to acting in a particular way. When these demands cannot be easily satisfied with available physical, psychological, social or material resources, and when demands come into conflict with personal goals, beliefs and expectations, they become a powerful source of stress (Lazarus, 2000).

Specifically in the occupational area, and following this line of thought, the World Health Organization defined burnout as the result of an imbalance between the demands and pressures of work, on the one hand, and the knowledge and abilities of workers, on the other hand (Leka et al., 2004). Regarding the educational context, various investigations have allowed the identification of those demands and working conditions that are habitually perceived as threatening and boosters of physical and psychological discomfort among teachers in nonisolation conditions. Among the most commonly signaled risk factors are: (a) behavioral problems, demotivation, absences and accidents suffered or provoked by students, (b) problems with the families of the students (criticism, complaints and lack of accompaniment to the student), (c) lack of support among colleagues, poor coordination and difficulties in teamwork, (d) administrative demands, conflict with superiors, injustices and low social and remunerative recognition, (e) work overload (multiple and excessive tasks to carry out in short periods of time and without sufficient breaks), (f) conflict and role ambiguity, (g) inadequate physical environment, lack of pedagogic material and lack of adequate equipment, (h) use of new technologies and (i) difficulties in combining work and family (Lambert et al., 2001; Salanova et al., 2003; Urquidi Treviño and Rodríguez Jiménez, 2010; Menghi, 2015; Goebel and Carlotto, 2019).

In the United States, a scale was created to assess the stress associated with different demands and resources peculiar to teaching work in primary schools based on the theoretical model of Lazarus and Folkman (1986) specifically (Lambert et al., 2001). The demands included behavior problems and student absences, administrative demands, a shortage of teaching materials, and so on. Among the resources, the availability and help of school support personnel, administrative support, community support and specialized training were assessed. The researchers noted a higher risk of occupational stress in those teachers who perceived high demands and low resources (Lambert et al., 2019).

The epidemiological situation framing the exercise of teaching today generates other concerns that are not inherent to the teaching role, but with a possible catalytic effect, such as fear of contagion, uncertainty about the duration of the pandemic and its possible impact on the economic situation, the physical distancing from social support networks, among others (MacIntyre et al., 2020; Sánchez Mendiola et al., 2020).

As a result, psychophysical manifestations of distress might emerge, with more or less severe consequences, depending on the case. Studies carried out with education professionals during the pandemic have reported an increase in headaches, muscle contractures, fatigue, anxiety, anguish, dizziness, lightheadedness, nervousness, and sleeping and eating disorders (Asociación del magisterio de Santa Fe, 2020; Confederación de Trabajadores de la Educación de la República Argentina, 2020; Sindicato Argentino de Docentes Particulares, 2020; Sindicato Unificado de Trabajadores de la Educación de Buenos Aires, 2020; Casali and Torres, 2021; Idris et al., 2021).

Moreover, it is known that when the teaching workload is perceived as higher than the resources available to meet it, the intention to continue practicing the profession, or choose it again if the opportunity arises, decreases significantly (Lambert et al., 2019). On the other hand, inadequate and long-term efforts to meet work demands can lead to burnout syndrome.

In current research on burnout syndrome, Maslach and Jackson's $(1981,1986)$ definition is the most widely accepted by the scientific community and belongs to the multidimensional model they develop. According to these authors, burnout syndrome is an individual stress experience embedded in a context of complex social relationships that encompasses the concept the person has of themselves and others. Moreover, they defined it as a psychological syndrome of emotional exhaustion (i.e., drainage or reduction of emotional resources produced by interpersonal demands), depersonalization (i.e., development of negative, insensitive and cynical attitudes toward the recipient) and low personal fulfillment at work (i.e., tendency to negatively evaluate the work done) that can be developed in individuals in any type of activity whose object of work are people. 
Gil-Monte and Peiró (1997) state that the burnout syndrome should be understood as a response to work stress that arises when the coping strategies the subject initially uses are not successful. The individual develops feelings of low personal fulfillment at work and emotional exhaustion by not being able to cope effectively with the stressors. Later on, the person displays behaviors of depersonalization as a new way of confrontation. Taking the transactional models as a reference, these authors recognize burnout as a variable that mediates between the stressors and their long-term effects. Within this context, burnout syndrome may be considered as an intermediate step in the stress-consequences of stress relationship.

Many studies have shown that stress and burnout are a potential problem within a wide range of occupations (Maslach et al., 2001; Schaufeli, 2003; Gil-Monte, 2005; Schaufeli et al., 2009). As regards teaching, studies conducted in different parts of the world have found that an important number of teachers are suffering from burnout syndrome (e.g., Fernández, 2002; Figueiredo-Ferraz et al., 2009; Rionda Arjona and Mares Cárdenas, 2011; Arias Gallegos and Jiménez Barrios, 2013; Ratto Dattoli et al., 2015), who show, in some cases, higher levels of burnout as compared to other occupations (e.g., Schaufeli and Enzmann, 1998; de Heus and Diekstra, 1999; Schaufeli, 2003; Johnson et al., 2005).

Although in recent years there has been interesting progress regarding the study of stress and burnout in Latin American teachers, new and more complex approaches are needed (LuyMontejo et al., 2019). This research intends to expand the knowledge of these variables in a historical moment in which health care and well-being of educators are crucial. As it was expressed before, the conditions of isolation and social distancing imposed new potentially stressful and possibly more aversive challenges due to their cumulative effect that is associated to other factors typical of the pandemic. Given this context, it is urgent and necessary to know the levels of stress and burnout education professionals express. Mainly, because several studies portray the harmful consequences these maladjustments carry for the educators who suffer from them, for the students and for the organization where they work (see Maslach et al., 2001; Schaufeli, 2003; Schaufeli and Buunk, 2002). Considering this background, this study seeks to identify the working conditions that education professionals perceive as threatening in times of pandemic, and describe the level of perceived stress and its possible effect on psychophysical symptoms. Additionally, this study intends to identify differences in the manifestations of burnout according to the level of perceived stress and associated symptoms.

Based on the interactional model by Lazarus and Folkman (1986), significant differences are hypothesized in the experience of stress symptoms according to the level of perceived threat. The higher the perception of threat, the higher the cognitive deficit, the nervousness and the physical symptomatology. On the other hand, taking into consideration Maslach and Jackson's (1986) classical approach (1986) and current research on stress and burnout syndrome in the teacher population (e.g., Esteras et al., 2016; Granados et al., 2019; Seijas-Solano, 2019), significant differences are hypothesized in the manifestations of burnout according to the perception of threat and the symptoms of stress.
The higher the perception of threat and the symptoms of stress, the greater the burnout.

\section{MATERIALS AND METHODS}

\section{Type of Study and Design}

An empirical, quantitative, ex post-facto, cross-sectional survey design was carried out (Calderón Saldaña and Alzamora de los Godos, 2018).

\section{Participants}

In this study, 9,058 teachers residing in different Argentinian provinces participated. They worked in public or private education institutions, or both, in one of the four educational levels, in special or permanent education of youngsters and adults. The selection of participants was conducted through a non-randomized procedure of volunteer recruitment. Demographic and working characteristics of the sample are exposed in Table 1. The registered teachers completed all the required tests. The test basis was free of missing data.

\section{Instruments}

In order to collect information about the demographic and working characteristics of the participants, closed questions were used, which revealed information regarding gender, age, educational level, work seniority and institutional management, among other aspects.

In order to analyze the situations that teachers perceive as stressful, a Scale of Teachers' Stressors in Times of Pandemic (Oros et al., 2020) was used, which consists of 21 items, with five Likert-type answer options (Not stressful =1, A little stressful $=2$, Somewhat stressful $=3$, Quite stressful $=4$, Very stressful $=5$ ). The items are factorially grouped into five factors: work environment and work overload (e.g., Having little time to do all the tasks involved in remote work), use of new technologies (e.g., Learning how to use and master new technologies), uncertainty about the duration and consequences of the pandemic for the teacher and the students (e.g., Feeling uncertain toward the future, not knowing when the pandemic will end), the organizational aspect of the educational institution (e.g., Feeling that superiors do not understand the difficulties of working under these conditions), and relationship with the students' environment, conflict and role ambiguity (e.g., Receiving multiple and simultaneous inquiries from students and/or parents). The internal consistency values reported by the authors ranged between $\omega=0.78$ and 0.85 for the factors, being of $\omega=0.93$ for the full scale. In this study, the values obtained were: alpha $=0.85$ for Work environment and work overload factor, alpha $=0.80$ for Use of new technologies factor, alpha $=0.83$ for Uncertainty about the duration and the consequences of the pandemic for the teacher and the students factor, alpha $=0.81$ for Organizational aspect of the educational institution factor, and alpha $=0.77$ for Relationship with the students' environment, conflict and role ambiguity factor.

In order to know the symptoms of stress, the Scale of physical psychoemotional indicators of stress (Oros and Neifert, 2006) 
was administered. This scale consists of 22 items grouped in three dimensions: Cognitive deficit (e.g., "I find it difficult to focus," "I forget things easily") (alpha $=0.79$ ), Nervousness (e.g., "I get nervous easily," "I feel I worry excessively about everything" (alpha $=0.74$ ) and physical symptoms ("I have insomnia or difficulty in falling asleep," "I have neck and back pain" (alpha $=0.62)$. The items were answered in a Likert scale with five answer options (Never, Hardly ever, Sometimes, Often, Always). The internal consistency values for this study sample were: alpha $=0.84$ for Cognitive deficit, alpha $=0.86$ for Nervousness, and alpha $=0.74$ for Physical symptoms.

Finally, in order to evaluate the burnout, a Spanish adaptation by Seisdedos (1997) of the Maslach Burnout Inventory (MBI), by Maslach and Jackson (1986) was used. This instrument consists of 22 items assessed with a Likert-type scale. Individuals indicate, through a range of seven adjectives, ranging from "Never" (0) to "Every day" (6), how often they experience each of the situations described. The factorization of the 22 items shows three orthogonal factors, which are called: (a) Emotional exhaustion, (b) Depersonalization, and (c) Personal fulfillment. The study of the MBI internal consistency in its original version in English showed, through the Cronbach alpha index, good values for each of the three subscales $(0.90$ for Emotional exhaustion, 0.79 for Depersonalization, and 0.71 for Personal fulfillment). In our country and region, this selfadministered inventory has been used in various studies, showing pyschometric properties between moderately acceptable and satisfactory (e.g., Marucco et al., 2009; Malander, 2019). In this sample, Cronbach alpha values were very good for Emotional exhaustion (0.89) and Personal fulfillment (0.85), and fairly acceptable for Depersonalization (0.64).

\section{Data Collection Procedures}

Due to the special conditions of social isolation in which this research was developed, the data collection was made through an online form. Volunteer recruitment was carried out through social media, electronic mail and digital messaging services, in some cases with the support of institutional and jurisdictional education authorities. The activity demanded approximately $15 \mathrm{~min}$. The data collection started 46 days after the preventive social isolation was decreed in our country, in a period between April 27 and September 15, 2020. Teachers were provided with an email address for inquiries and an optional section at the end of the form to express opinions and comments.

\section{Statistical Procedures}

The teachers' answers were quantified and statistically processed. No missing data were recorded either at an item level or at a scale level.

To identify the situations valued as threatening, and the level of perceived stress, basic statistical analyses were conducted (calculus of means and standard deviations). In order to make descriptive comparisons between the different dimensions of the Stressor Scale, these means were considered by the number of items in each dimension.

The percentages of adherence to each answer section were calculated so as to estimate the general level of stress teachers perceived, taking into consideration the options of the Likert scale that were used in the evaluation (Not stressful $=1$, A little stressful $=2$, Somewhat stressful $=3$, Quite stressful $=4$, Very stressful $=5$ ). In that way, scores weighted between 1 and 2 were considered indicative of Low level of stress, scores between 2.01 and 3 as indicative of moderately low level of stress, scores between 3.01 and 4 as moderately high, and scores over 4.01 as a high level of stress perception.

The assumptions of homoscedasticity and normality of the variables (univariate and multivariate) were also tested to determine the most adequate statistical test to study the hypotheses. For this purpose, the Kolmogorov-Smirnov, Box, Bartlett and Levene tests were used, from which the noncompliance with the mentioned assumptions was confirmed.

Therefore, with the purpose of analyzing possible differences among the psychophysical symptoms according to the level of stress, a non-parametric Kruskal Wallis $H$ analysis was performed. Previously, the scores for each stressor were categorized in four groups (low stress, moderately low stress, moderately high stress and high stress) using the same criteria as with the general value. The Kruskal Wallis $H$ test was also used to investigate the differences in the three manifestations of burnout based on perceived stress on the one hand, and psychophysical symptoms on the other. The psychophysical symptoms variable was categorized for this analysis using two cut points $(<33.33=$ low symptomatology, 33.33-66.66 $=$ moderate symptomatology, $>66.66=$ high symptomatology).

The effect size for the $H$ tests was estimated with the squared epsilon statistical $\left(E_{R}^{2}\right)$, considering for its interpretation the Cohen's criteria for the analogous test of partial eta ${ }^{2}: 0.01$ (small), 0.06 (moderate) and 0.14 (large). In all cases, post hoc contrasts were conducted through the non-parametric Mann-Whitney $U$-test.

\section{Ethical Considerations}

The actions carried out in this work complied with the international ethical recommendations for research with human beings (i.e., Asamblea Médica Mundial, 2013; American Psychological Association, 2017). The teachers participated anonymously and voluntarily, stating their consent before answering the instructions on the form. No incentives of any kind were provided in exchange for participation. The information collected was treated confidentially, and was not accessed by persons outside the investigation.

\section{RESULTS}

\section{Situations Valued as Threatening and Level of Perceived Stress}

According to the analysis of weighted means, of the five major stressors that were assessed, the preeminence of Uncertainty about the duration and the consequences of the pandemic is highlighted, followed in order of importance by Work environment and work overload, Relationship with the students' environment, conflict and role ambiguity, Organizational aspect 
TABLE 1 | Demographic and working characteristics of the participants $(n=9.058)$.

\begin{tabular}{lcccc}
\hline Variables & Frequency & Percentage & Mean & SD \\
\hline Gender & & & & \\
Female & 7,870 & 86.90 & & \\
Male & 1,182 & 13.00 & & \\
Other & 6 & 0.10 & & \\
Age & & & & \\
Educational level or modality in & & & & \\
which they perform & 1,057 & 11.70 & & \\
Kindergarden education & 3,865 & 42.70 & & \\
Primary education & 2,592 & 28.60 & & \\
Secondary education & 349 & 3.90 & & \\
Higher education & 573 & 6.30 & & \\
Special education & 622 & 6.90 & & \\
Continuing education of young & & & & \\
people and adults & & & & \\
Seniority in teaching & & & & \\
\hline SD Standard Deviation. & & & & \\
\hline
\end{tabular}

SD, Standard Deviation.

TABLE 2 | Descriptive information of the main variables.

\begin{tabular}{lcccccc}
\hline Variables & Min & Max & $\boldsymbol{M}$ & SD & Skewness & Kurtosis \\
\hline Teachers' stressors & & & & & & \\
Environment and work overload & 1 & 5 & 3.37 & 1.09 & -0.38 & -0.83 \\
Uncertainty & 1 & 5 & 3.64 & 0.96 & -0.54 & -0.49 \\
Organizational aspect & 1 & 5 & 3.10 & 1.12 & -0.03 & -1.01 \\
Relationships and role & 1 & 5 & 3.14 & 1.12 & -0.08 & -0.95 \\
New technologies & 1 & 5 & 3.10 & 1.05 & -0.05 & -0.92 \\
Psychophysical symptoms & & & & & & \\
Cognitive deficit & 0 & 28 & 11.03 & 5.27 & 0.14 & -0.26 \\
Nervousness & 0 & 28 & 13.92 & 5.61 & -0.12 & -0.02 \\
Physical symptoms & 0 & 32 & 15.21 & 5.64 & -0.07 & -0.21 \\
Burnout & & & & & & \\
Emotional exhaustion & 0 & 54 & 23.86 & 13.29 & 0.12 & -0.91 \\
Personal fulfillment & 0 & 48 & 36.79 & 9.39 & -1.05 & 0.76 \\
Depersonalization & 0 & 30 & 3.97 & 5.30 & 1.84 & 3.83 \\
\hline
\end{tabular}

Min, Minimum value of the subscale; Max, Maximum value of the subscale; M, Mean; SD, Standard deviation.

of the educational institution, and Use of new technologies factors (see Table 2).

On the other hand, statistical analyses revealed that $62.1 \%$ of teachers in the sample display general levels of stress between moderately high and high.

\section{Experience of Psychophysical Symptoms According to the Level of Stress}

The analysis indicated significant differences in the psychophysical symptomatology according to the levels of perceived stress. The size of these differences was between moderate and large, the largest being the cognitive deficit. Post hoc contrasts showed significant differences among all the comparison groups, for all the variables included in the analysis $(p<0.001)$. The frequency with which physical symptoms, nervousness, and cognitive deficit are experienced increases significantly as the perception of stress increases (see Table 3).

\section{Manifestations of Burnout According to Level of Stress and Psychophysical Symptoms}

The results revealed statistically significant differences in the three dimensions of Burnout depending on the level of stress. The size of the effect was larger for the Emotional exhaustion dimension (see Table 4). The post hoc contrasts showed significant differences among all the comparison groups for the dimensions of Emotional exhaustion and Depersonalization, whereas for Personal fulfillment a few pairs of non-significant average ranges were observed (see Table 5). In general, it is observed that as the level of stress increases, Exhaustion and Depersonalization increase, and Personal fulfillment decreases. An exception to this tendency was seen in Uncertainty about the consequences of the pandemic factor; in this case, both high and low levels of stress were associated with lower Personal fulfillment.

Statistically significant differences were also observed in the three dimensions of Burnout according to the frequency of the psychophysical symptoms experienced. Again, the effect size was larger for Emotional exhaustion (see Table 6). The post hoc contrasts showed significant differences among all the comparison groups, for all the variables included in the analysis $(p<0.001)$. The higher the score in Cognitive deficit, Physical symptoms and Nervousness, the higher the score in Emotional Exhaustion and Depersonalization, but the lower the score in Personal fulfillment.

\section{DISCUSSION}

This study was conducted with the objective of: (a) identifying the workplace situations that teachers perceive as threatening in times of pandemic, (b) describing the level of perceived stress and its effect on the psychophysical symptoms, and (c) studying possible differences in burnout according to the level of perceived stress and associated symptoms. Hereinafter, the obtained results will be discussed, with reference to their adjustment degree with the previously stated hypotheses.

\section{Situations Valued as Threatening and Level of Perceived Stress}

Of the five stressors assessed, uncertainty about the consequences of the pandemic for the teacher and the student stood out for its intensity (e.g., not knowing how the socioeconomic situation will continue, knowing there are students who do not have the technological resources to work remotely, being uncertain about the future, not knowing when the pandemic will end, and not knowing if students are understanding the contents). Preeminence of stressors associated with the working environment and work overload was observed (e.g., overlapping of work with household tasks, work schedule that is disorderly, unpredictable or different from the usual schedule, 
TABLE 3 | Results of the Kruskall Wallis test for the Psychophysical symptoms according to the Level of stress.

\begin{tabular}{|c|c|c|c|c|c|c|c|c|c|}
\hline \multirow[t]{3}{*}{ Level of stress } & \multicolumn{9}{|c|}{ Psychophysical symptoms } \\
\hline & \multicolumn{3}{|c|}{ Cognitive deficit } & \multicolumn{3}{|c|}{ Physical symptoms } & \multicolumn{3}{|c|}{ Nervousness } \\
\hline & AR & $\mathbf{H}$ & $E^{2} R$ & AR & $\mathbf{H}$ & $\mathrm{E}^{2}{ }_{\mathrm{R}}$ & AR & $\mathbf{H}$ & $\mathrm{E}^{2}{ }_{\mathrm{R}}$ \\
\hline \multicolumn{10}{|c|}{ Environment and work overload } \\
\hline Low & 2509.09 & $2020.33^{\star \star \star}$ & 0.22 & 2855.21 & $1575.19^{\star \star \star}$ & 0.17 & 2715.17 & $1860.83^{\star \star \star}$ & 0.21 \\
\hline High & 6007.08 & & & 5870.17 & & & 5976.23 & & \\
\hline \multicolumn{10}{|c|}{ Use of new technologies } \\
\hline Low & 2999.28 & $1376.91^{\star \star \star}$ & 0.15 & 3396.87 & $805.75^{\star \star \star}$ & 0.09 & 3255.51 & $1028.28^{\star \star \star}$ & 0.11 \\
\hline Moderately low & 4129.24 & & & 4216.52 & & & 4137.52 & & \\
\hline Moderately high & 5068.12 & & & 4873.68 & & & 4978.98 & & \\
\hline Low & 2766.42 & $1254.52^{\star \star \star}$ & 0.14 & 3072.99 & $939.62^{\star \star \star}$ & 0.10 & 2939.71 & $1077.14^{\star \star \star}$ & 0.12 \\
\hline Moderately low & 3403.51 & & & 3585.95 & & & 3508.31 & & \\
\hline Moderately high & 4457.98 & & & 4394.04 & & & 4413.40 & & \\
\hline High & 5593.49 & & & 5485.73 & & & 5539.48 & & \\
\hline \multicolumn{10}{|c|}{ Organizational aspect } \\
\hline Low & 2999.83 & $1416.80^{\star \star \star}$ & 0.16 & 3226.55 & $1056.38^{\star \star \star}$ & 0.12 & 3140.00 & $1214.16^{\star \star \star}$ & 0.13 \\
\hline Moderately low & 4178.77 & & & 4210.08 & & & 4171.52 & & \\
\hline Moderately high & 5070.38 & & & 4978.76 & & & 5023.18 & & \\
\hline High & 5899.99 & & & 5737.15 & & & 5820.77 & & \\
\hline \multicolumn{10}{|c|}{$\begin{array}{l}\text { Relationships with the student } \\
\text { environment, conflict and } \\
\text { ambiguity of role }\end{array}$} \\
\hline
\end{tabular}

$A R$, Average range; $H$, Kruskall Wallis test; $E^{2}$, Epsilon squared effect size. ${ }^{* * *} p<0.001$.

and lack of time to perform the tasks involved in remote work), as well as organizational aspects of the educational institution (e.g., receiving a greater number of requirements and demands from superiors), and the relationship with the students' environment (e.g., receiving multiple and simultaneous inquiries from students and/or parents). As regards stress, it was noticed that $62.1 \%$ of educators presented high and moderately high levels of stress.

Similarly, studies conducted with Latin American teachers reported that they presented high levels of stress, anguish and anxiety during the suspension of face-to-face classes due to the global COVID-19 pandemic (Becerra Hernández, 2020; Casimiro Urcos et al., 2020). In Europe, under the same circumstances, Klapproth et al. (2020) found that German teachers experienced moderately high levels of stress on average. Likewise, they found that most educators pointed to the lack of technological equipment, internet connectivity, excessive workload and students' demotivation as internal and external obstacles that made distance educational work difficult.
MacIntyre et al. (2020) examined work stressors that teachers who taught foreign languages in different educational levels and countries were exposed during school closings. These authors found that teachers identified work overload and concern for their family's health as the most stressful. This was followed by loss of control over work, overlapping of work with household tasks, loss of control over personal decisions, irregular schedules and concern about finances. Coinciding with this study, they also highlighted that some educators mentioned not knowing when the pandemic would end as a source of stress.

In Argentina, between the months of April and June of 2020 , different syndicates conducted studies in order to learn about aspects associated with the health and working conditions of educators of all educational levels and modalities, in the context of isolation and mandatory social distancing. These organizations reported that most teachers pointed out their work-related activities had increased and demanded more time. Consequently, they had to dedicate more hours to their 
TABLE 4 | Results of the Kruskall Wallis test of variance for Burnout according to the Level of stress.

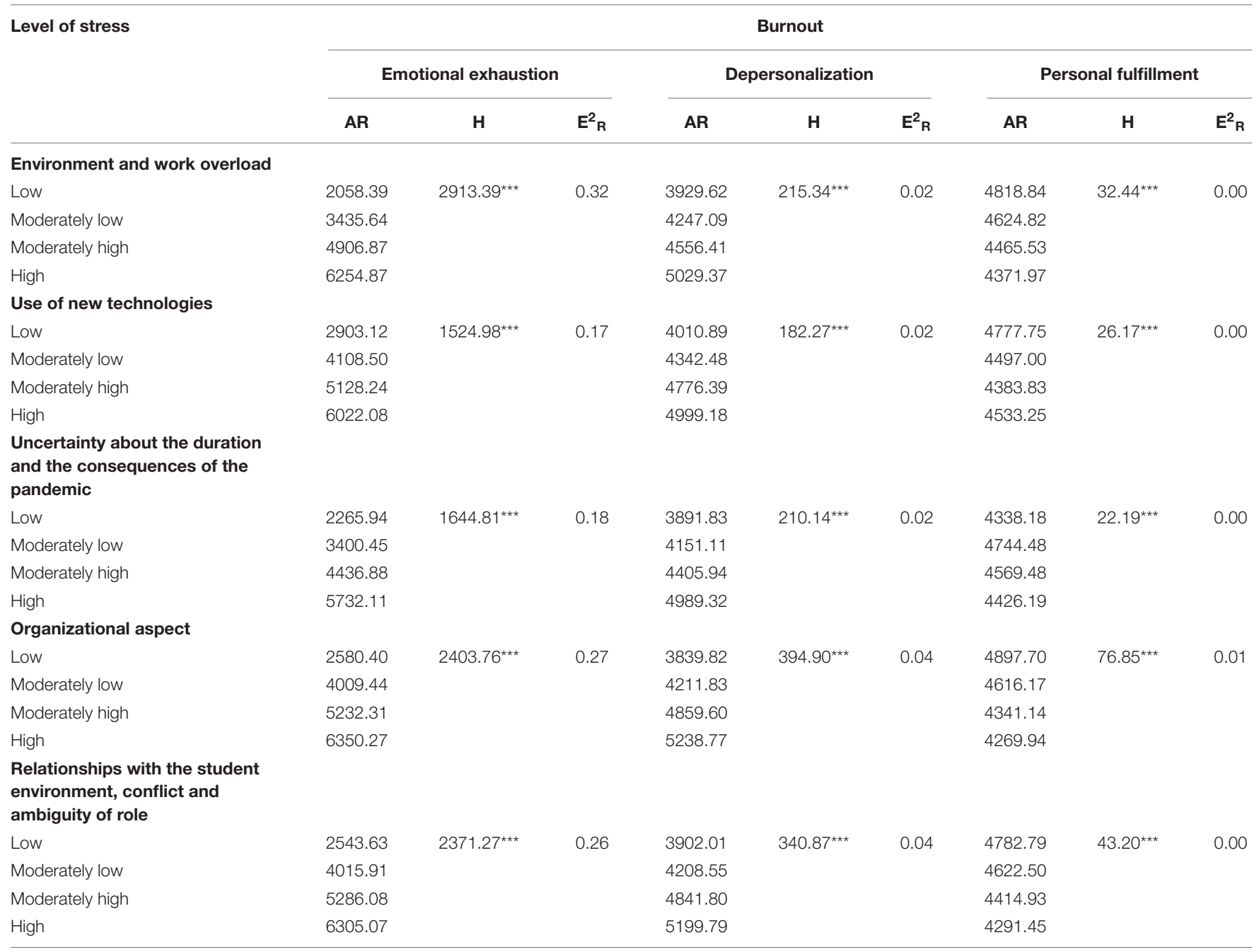

AR, Average range; $H$, Kruskall Wallis test; E2R, Epsilon squared effect size.

${ }^{* * *} p<0.001$.

TABLE 5 | U de Mann Whitney values of the post hoc contrasts for Personal fulfillment according to the Levels of stress.

\begin{tabular}{|c|c|c|c|c|c|c|}
\hline Stress factors & L/ML & L/MH & L/H & ML/MH & $\mathrm{ML} / \mathrm{H}$ & MH/H \\
\hline 2 & $2404464.5^{\star \star \star}$ & $2379220.5^{\star \star \star}$ & $1585064.5^{\star \star}$ & 3538759.5 & 2322003.5 & 2298818 \\
\hline 4 & $2431776^{\star \star \star}$ & $2291782^{\star \star \star}$ & $1790543^{\star \star \star}$ & $2911322^{\star \star \star}$ & $2275758^{\star \star \star}$ & 2438424 \\
\hline 5 & $2465516.5^{\star}$ & $2443509.5^{\star \star \star}$ & $1739315^{\star \star \star}$ & $3111660.5^{\star *}$ & 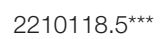 & 2405541 \\
\hline
\end{tabular}

L, Low; ML, Moderately low; MH, Moderately High; H, High; 1 = Work environment and work overload; 2, Use of new technologies; 3, Uncertainty about the duration and the consequences of the pandemic; 4, Organizational aspect of the educational institution; 5, Relationships with the student environment, conflict and ambiguity of role. ${ }^{*} p<0.05,{ }^{* *} p<0.01,{ }^{* * *} p<0.001$.

daily work. A high percentage of educators reported not having adequate technological resources nor a comfortable isolated place to work at home. Moreover, combining workrelated activities, household task and caring for their children, elderly or other family members was largely problematic for teachers. They also reported receiving communications outside working hours and contradictory instructions from educational authorities. Likewise, they revealed difficulties in supporting students' schooling, mainly because many students did not have the necessary equipment and connectivity to work from home. Lastly, a significant number of educators expressed feeling concerned, anguished and suffering from stress (see Asociación del magisterio de Santa Fe, 2020; Confederación de Trabajadores de la Educación de la República Argentina, 2020; 
TABLE 6 | Results of the Kruskall Wallis test of variance for Burnout according to the Level of symptoms.

\begin{tabular}{|c|c|c|c|c|c|c|c|c|c|}
\hline \multirow[t]{3}{*}{ Symptoms of stress } & \multicolumn{9}{|c|}{ Burnout } \\
\hline & \multicolumn{3}{|c|}{ Emotional exhaustion } & \multicolumn{3}{|c|}{ Depersonalization } & \multicolumn{3}{|c|}{ Personal fulfillment } \\
\hline & AR & $\mathbf{H}$ & $E^{2} R$ & AR & $\mathbf{H}$ & $E^{2} R$ & AR & H & $E^{2} R$ \\
\hline \multicolumn{10}{|l|}{ Cognitive deficit } \\
\hline Low & 2864.06 & $2975.03^{\star \star \star}$ & 0.33 & 3859.85 & $535.62^{\star \star \star}$ & 0.06 & 5248.29 & $503.27^{\star \star \star}$ & 0.06 \\
\hline Moderate & 4681.17 & & & 4557.81 & & & 4360.79 & & \\
\hline High & 6426.26 & & & 5321.55 & & & 3803.74 & & \\
\hline \multicolumn{10}{|l|}{ Physical symptoms } \\
\hline Low & 3055.60 & $2055.72^{\star \star \star}$ & 0.23 & 3980.93 & $259.37^{\star \star \star}$ & 0.03 & 5337.08 & $528.64^{\star \star \star}$ & 0.06 \\
\hline Moderate & 4742.23 & & & 4722.83 & & & 4254.79 & & \\
\hline High & 6160.81 & & & 4991.77 & & & 3836.38 & & \\
\hline \multicolumn{10}{|l|}{ Nervousness } \\
\hline Low & 2941.14 & $2468.81^{\star \star \star}$ & 0.27 & 3878.74 & $383.32^{\star \star \star}$ & 0.04 & 5365.19 & $606.29^{\star \star \star}$ & 0.07 \\
\hline Moderate & 4687.02 & & & 4721.97 & & & 4317.44 & & \\
\hline High & 6269.67 & & & 5106.17 & & & 3751.54 & & \\
\hline
\end{tabular}

AR, Average range; $H$, Kruskall Wallis test; $E 2_{R}$, Epsilon squared effect size.

${ }^{* * *} p<0.001$.

Sindicato Argentino de Docentes Particulares, 2020; Sindicato Unificado de Trabajadores de la Educación de Buenos Aires, 2020).

\section{Experience of Psychophysical Symptoms According to the Level of Stress}

Results indicated that as the perception of stress increases, so do cognitive deficit, nervousness and various physical symptoms. These findings confirm the initial hypothesis and are consistent with the preliminary report by Arias et al. (2020). The authors observed that after 60 days of the onset of the quarantine in Argentina, teachers reported a significant increase in their workload and that this was associated to physical symptoms, especially lower back pain and discomfort in their arms and wrists. Similarly, Nieva's (2020) study, conducted in Argentina during the context of social isolation due to COVID-19, registered a positive and significant correlation among various occupational stressors, somatization and other psychological symptoms in teachers. Likewise, $62 \%$ of Argentine teachers consulted by Casali and Torres (2021) expressed having worsened some psychophysical signs linked to stress in the context of the pandemic.

Similar results have also been documented before the onset of this sanitary contingency. For instance, Oramas Viera et al. (2007) assessed a sample of Venezuelan teachers, observing that the perception of stressors was positively and statistically significantly related to different functional symptoms (cognitive, affective, conative and psychosomatic). Comparably, Harmsen et al. (2019) found that the perception of stressors in teachers in the Netherlands kept a positive correlation with various stress responses, such as loss of pleasure, poorer sleep quality, fatigue, etc.

The general stress model proposed by Lazarus and Folkman (1986) and later taken up by Peiró and Salvador (1993) to explain work stress provides a solid frame for the interpretation of these results. According to their postulates, the stimuli that are perceived as threatening, in this case coming from the occupational context of teaching, produce a series of changes in the individual at a social, emotional and physiological level. These changes, with immediate and long-term effects, may produce suffering and deterioration of health and well-being (Ramos et al., 1997). Lazarus (2000) states that stress processes affect health in two ways. In the first place, they alter the neurochemistry of the body, that is, chemical and hormonal defenses that produce changes in sympathetic activity, secretion of catecholamines, etc., are activated as a reaction to stress (Krantz et al., 1985). Secondly, stress may favor the adoption of dysfunctional behaviors and coping styles. People exposed to situations perceived as stressful may attempt to obtain relief through the implementation of inadequate strategies, such as the consumption of alcohol, tobacco and other harmful substances, and excess or lack of food, which would derive in several psychophysical ailments.

On the other hand, some specific symptoms, such as those associated with the lower back, may be clearly explained by the large number of hours that teachers had to work sitting down in their own homes, possibly in an incorrect posture and/or using ergonomically inadequate furniture. Similarly, the excess of activities, the lack of time and the impossibility of leaving their residencies (due to the isolation dispositions) may have significantly increased sedentary lifestyles, also generating the appearance or exacerbation of these symptoms and others associated to the quality of sleep, to eating habits or to mental state (Bane et al., 2021).

Beyond the particular impact the stated situations may have had, it was probably the combination of all that explained the manifestation of various psychophysical symptoms presented when facing the stress involved in teaching in such particular contextual conditions. 


\section{Manifestations of Burnout According to the Level of Stress and Psychophysical Symptoms}

The results showed that as stress increases, so do Emotional exhaustion and Depersonalization, with Emotional exhaustion having a greater size effect. Regarding personal fulfillment, it was observed that, in general, it decreases as the perception of stress increases. It was also noted that the more teachers experience Cognitive deficit, Physical symptoms and Nervousness, the lower their Personal fulfillment, and the higher their Emotional exhaustion and Depersonalization. These results confirm the second hypothesis presented in this study.

Studies conducted with teachers before the COVID-19 pandemic was declared have reported results similar to those obtained in this study. For instance, a study with Venezuelan teachers found that Burnout syndrome was significantly correlated with the perception of stress and its symptoms. In this study, Emotional exhaustion also showed a higher correlation with perception of stress and psychophysical symptoms (Oramas Viera et al., 2007). In a similar way, a research conducted with Portuguese teachers found that the perceived stress was inversely proportional to Personal fulfillment and directly proportional to Emotional exhaustion and Depersonalization (Teles et al., 2020).

As stated before, burnout syndrome is a prolonged response to chronic stressors at work. It appears when the coping strategies used to handle work stressors are not functional. The individual, unable to mitigate or eliminate the source of stress, generates a series of physiological, cognitive, affective, attitudinal and behavioral responses that work as mediating variables between perceived stress and its consequences (GilMonte, 2005; Maslach, 2009). In this context, it is possible to think that teachers who experienced intense levels of work stress under the non-face-to-face teaching modality may have used ineffective coping strategies. In response, they possibly saw their emotional resources depleted, developed negative attitudes toward the students and experienced feelings of low competence and success at work.

It was surprising that, in reference to Uncertainty about the consequences of the pandemic for the teacher and the student dimension, both high and low levels of stress were associated with lower Personal fulfillment. This finding is partially dissenting with the starting hypothesis, and not easy to interpret, especially considering the lack of empirical background on the topic. It would be appropriate to deepen on this topic in future research.

\section{CONCLUSION, RECOMMENDATIONS AND LIMITATIONS OF THE STUDY}

In conclusion, it is possible to assert that a large proportion of Argentine teachers were significantly affected by occupational stress during the suspension of face-to-face classes. During this period, the stressors with a higher impact were associated with pandemic concerns and work overload, which, along with other situations perceived as threatening, explained the appearance of various psychophysical symptoms and burnout.
Based on these results, it would be desirable that national, jurisdictional and institutional education authorities critically reviewed the administrative protocols that were used during the so called first wave of cases, in order to adjust communication, planning, assessment and supervision procedures that have exceeded the actual capacities of many teachers (in terms of time, knowledge, technological skills, etc.). This review would be crucial to provide good quality education to students and offer better working conditions to educators, for as long as the pandemic lasts, schooling in Argentine educational institutions will be faceto-face, non-face-to-face or combined, depending on the epidemiological conditions.

At the same time, and beyond the measures educational institutions may carry out for the benefit of teachers, it is compelling that from health psychology instances that promote the psychosocial resources of teachers are generated. The results of this study could be capitalized to implement intervention measures (workshops, trainings, focus groups) aiming at reducing teacher discomfort and strengthening those resources that enhance the recovery and protection of their health and wellbeing. In this sense, it is especially recommended to strengthen teachers' engagement, social support networks, existential beliefs and locus of control, social skills and functional coping strategies (Lazarus and Folkman, 1986). Similarly, it is suggested to offer seminars and guidance on how to optimize physical health and prevent discomfort, putting emphasis on, for instance, indications on correct body posture, good sleeping and eating habits, physical exercise, among others.

Although several months have passed since the beginning of the sanitary contingency, and teaching is no longer exclusively remote in formal education, it is possible that educators continue to perceive several demands as stressful, especially because of their changing nature. If no psycho-educational and therapeutic alternatives that allow the drainage of tensions are offered to educators, their psychophysical state may continue to deteriorate with serious long-term consequences, both at personal level (e.g., health loss, demotivation), and at organizational level (e.g., absenteeism, leaves, dropouts, decrease in the education quality).

This research presents some limitations that could be supplemented in future studies on this topic. Firstly, although the sample size was large, the lack of randomization restricts the generalization of the results. It would be desirable in future studies to extract random samples with representativeness from different regions of the country.

On the other hand, it should be noted that there are still no Argentine standardization studies that establish cut-off points for the interpretation of the variables analyzed here. For this reason, an ad hoc procedure based on sample frequencies and percentiles was used to categorize stress levels and psychophysical symptoms. In future studies, it is recommended to work on the development of normative values for the Argentine population.

In relation to the variables involved, this research has not included the analysis of coping, a variable that is crucial to deepen the understanding of stress and its possible consequences. It is 
recommended that its evaluation be included in future studies so as to determine how coping may mediate the relationship between perceived stress and its consequent burnout.

The cross-sectional nature of this study could also be considered a limitation, since no information is provided about the evolution of the perception of stressors, symptoms and burnout over time. This will be pending for future works.

\section{DATA AVAILABILITY STATEMENT}

The raw data supporting the conclusions of this article will be made available by the authors, without undue reservation.

\section{ETHICS STATEMENT}

Ethical review and approval was not required for the study on human participants in accordance with the local legislation and institutional requirements. The patients/participants provided their written informed consent to participate in this study.

\section{REFERENCES}

American Psychological Association (2017). Ethical Principles of Psychologists and Code of Conduct. Washington, DC: American Psychological Association.

Arias, C. F., Amieva López, A., and De Bortoli, M. A. (2020). "Carga de Trabajo y Síntomas Corporales en Docentes antes y desde la cuarentena por la pandemia de Covid-19 [Workload and body symptoms in teachers before and since quarantine by the Covid-19 pandemic] [Comunicación libre]," in Proceedings of the XIII Congreso Argentino de Salud Mental, Buenos Aires.

Arias Gallegos, W. L., and Jiménez Barrios, N. A. (2013). Síndrome de burnout en docentes de educación básica regular de arequipa [Burnout syndrome in educators of regular basic education from Arequipa]. Educación 22, 53-76.

Asamblea Médica Mundial (2013). Declaración de Helsinki de la AMM Principios Éticos Para las Investigaciones Médicas en Seres Humanos. Available online at: http://repositorio.mederi.com.co/bitstream/handle/123456789/386/ Declaracion-Helsinki-2013-Esp.pdf?sequence=1 (accessed December 3, 2020).

Asociación del magisterio de Santa Fe (2020). Docencia Santafesina: Condiciones de Trabajo Arrasadas [Teaching Santafesina: Working Conditions Razed]. Available online at: http://www.amsaferosario.org.ar/uploadsarchivos/ docencia_santafesina_condiciones_de_trabajo_arrasadas_1.pdf (accessed December 3, 2020).

Bane, J. V., Aurangabadkar, S., and Karajgi, A. (2021). Physical and self-perceived occupational stress associated with work from home situation in teachers during the COVID-19 pandemic. Intern. J. Health Sci. Res. 11, 117-124.

Becerra Hernández, T. Y. (2020). Estrés Laboral y Calidad de vida en Tiempos de Pandemia en Docentes de Escuelas con Quintil 1-Cajamarca [Work Stress and Quality of Life in Times of Pandemic in School Teachers With Quintil 1-Cajamarca]. Cajamarca: Universidad Privada Antonio Guillermo Urrelo.

Calderón Saldaña, J. P., and Alzamora de los Godos, L. (2018). Diseños de investigación para tesis de posgrado [Research designs for graduate thesis]. Rev. Peruana de Psicol. Trabajo Soc. 7, 71-76.

Carnese, F. (2020). Los Docentes Piden Ayuda Psicológica en la Pandemia [Teachers Ask for Psychological Help in the Pandemic]. La Mañana Neuquén. Available online at: https://www.lmneuquen.com/los-docentes-piden-ayudapsicologica-la-pandemia-n705934 (accessed December 3, 2020).

Casali, A., and Torres, D. (2021). Impacto del COVID-19 en docentes universitarios argentinos: cambio de prácticas, dificultades y aumento del estrés [Impact of COVID-19 on Argentine university teachers: change of practices, difficulties and increased stress]. Rev. Iberoam. Tecnol. Educ. Educ. Tecnol. 28, 423-431. doi: 10.24215/18509959.28.e53

\section{AUTHOR CONTRIBUTIONS}

$\mathrm{NV}$ was the originator of the idea, organized the database, and wrote sections of the manuscript. LO contributed to the design of the study, performed the statistical analysis, and wrote sections of the manuscript. Both authors contributed to the data collection, read, and approved the final manuscript.

\section{FUNDING}

This work was supported by Universidad Católica Argentina and Universidad Adventista del Plata.

\section{ACKNOWLEDGMENTS}

We thank the General Direction of Schools of the province of Mendoza and the Education Department of the Argentine Seventh-day Adventists Association for supporting the development of this work through its distribution in their respective jurisdictions.

Casimiro Urcos, W. H., Casimiro Urcos, C. N., Barbachán Ruales, E. A., and Casimiro Urcos, J. F. (2020). Stress, anguish, anxiety and resilience of university teachers in the face of Covid-19. Utopia y Praxis Latinoam. 25, 453-464.

Confederación de Trabajadores de la Educación de la República Argentina (2020). Informe de la Encuesta Nacional de CTERA "Salud y Condiciones de Trabajo Docente en Tiempos de Emergencia Sanitaria COVID19" [Report of the CTERA National Survey "Health and Conditions of Teaching Work in Times of Health Emergency COVID19"]. Available online at: https://www.ctera.org.ar/index.php/salud-laboral/publicaciones/item/3611informe-de-la-encuesta-ncional-de-ctera-salud-y-condiciones-de-trabajodocente-en-tiempos-de-emergencia-sanitaria-covid19 (accessed December 3, 2020).

de Heus, P., and Diekstra, R. (1999). "Do teachers burn out more easily? A comparison of teachers with other social professions on work stress and burnout symptoms," in Understanding and Preventing Teacher Burnout: A Sourcebook of International Research and Practice, eds E. R. Vandenberghe and A. Huberman (Cambridge: Cambridge University Press), 269-284. doi: 10.1017/CBO9780511527784.019

Di Vincenzo, D. (2020). Cuarentena Docente: Entre las Mamaderas, las Compras y las Clases Virtuales [Teacher Quarantine: Between Bottles, Shopping and Virtual Classes]. Buenos Aires: Infobae.

Esteras, J., Sandín, B., and Chorot, P. (2016). El Síndrome de Burnout en los Docentes: Los Efectos de las Variables Psicosociales [The Syndrome of Burnout in the Teachers: The Effect of Psychosocial Variables]. Philadelphia, PA: ACIPEAsociación Científica de Psicología y Educación.

Esteve, J. M. (1994). El Malestar Docente [The Teacher Malaise]. Barcelona: Paidós. Favant, B. (2020). El Testimonio de Docentes Santafesinas: "Las Aulas Nunca Estuvieron Vacías" [The Testimony of Teachers from Santa Fe: "The Classrooms Were Never Empty"]. Diario Uno Santa Fe. Available online at: https://www.unosantafe.com.ar/santa-fe/el-testimonio-docentes-santafesinaslas-aulas-nunca-estuvieron-vacias-n2592992.html (accessed December 3, 2020).

Fernández, M. (2002). Desgaste psíquico (burnout) en profesores de educación primaria de Lima metropolitana [Psychological burnout syndrome in elementary school teachers in metropolitan Lima]. Persona 5, 27-66. doi: 10.26439/persona2002.n005.842

Fernández, M. (2020). Los Docentes, Desbordados en Medio de la Pandemia: "Mi día a día se Convirtió en un Caos" [Teachers, Overwhelmed in the Midst of the Pandemic: "My Day to Day Turned Into Chaos"]. Buenos Aires: Infobae. 
Figueiredo-Ferraz, H., Gil-Monte, P. R., and Grau-Alberola, E. (2009). Prevalencia del síndrome de quemarse por el trabajo (Burnout) en una muestra de maestros Portugueses [Prevalence of burnout syndrome in Portuguese teachers]. Aletheia 29, 6-15.

Figueroa Díaz, A. (2020). Los Docentes, la Cuarentena y la Sobrecarga de las Clases a Distancia [Teachers, Quarantine and the Overload of Distance Classes]. Página 12. Available online at: https://www.pagina12.com.ar/263725-los-docentes-lacuarentena-y-la-sobrecarga-de-las-clases-a-d (accessed December 3, 2020).

Gil-Monte, P. R. (2005). El Síndrome de Quemarse por el Trabajo. Una Enfermedad Laboral en la Sociedad del Bienestar [The Syndrome of Burn by Work. An Occupational Disease in the Welfare Society]. Madrid: Ediciones Pirámide.

Gil-Monte, P. R., and Peiró, J. M. (1997). Desgaste Psíquico en el Trabajo: El Sindrome de Quemarse [Psychic Burnout at Work: The Burnout Syndrome]. Madrid: Síntesis.

Goebel, D. K., and Carlotto, M. S. (2019). Preditores da autoavaliação da Saúde Geral em docentes de Educação a Distância [Predictors of self-assessment of general health in teachers working in distance education]. Rev. Iberoamer. Educ. Dist. 22, 309-323. doi: 10.5944/ried.22.1.21885

Granados, L., Aparisi Sierra, D., Inglés, C. J., Aparicio Flores, P., Fernández-Sogorb, A., and García-Fernández, J. M. (2019). ¿Predicen los factores de depresión, ansiedad y estrés la dimensión de la despersonalización y la baja realización personal en el profesorado? [Do the depression, anxiety and stress factors predict the dimension of depersonalization and low personal accomplishment in professorate?]. Educ. Psychopathol. 7, 83-92. doi: 10.30552/ejpad.v7i1.91

Harmsen, R., Helms-Lorenz, M., Maulana, R., van Veen, K., and van Veldhoven, M. (2019). Measuring general and specific stress causes and stress responses among beginning secondary school teachers in the Netherlands. Intern. J. Res. Method Educ. 42, 91-108. doi: 10.1080/1743727X.2018.1462313

Idris, A. M., Audu, R., Binni, D. B., Arah, A. S., and Ajiya, U. M. (2021). Anxiety and stress symptoms associated with Covid-19 pandemic among teachers of vocational enterprises Institutes in Nigeria. ATBU J. Sci. Technol. Educ. 9, 126-134.

Johnson, S., Cooper, C., Cartwright, S., Donald, I., Taylor, P., and Millet, C. (2005). The experience of work-related stress across occupations. J. Manag. Psychol. 20, 178-187. doi: 10.1108/02683940510579803

Klapproth, F., Federkeil, L., Heinschke, F., and Jungmann, T. (2020). Teachers' experiences of stress and their coping strategies during COVID-19 induced distance teaching. J. Pedagogic. Res. 4, 444-452. doi: 10.33902/JPR.2020062805

Krantz, D. S., Grunberg, N. E., and Baum, A. (1985). Health psychology. Ann. Rev. Psychol. 36, 349-383.

Lambert, R., Boyle, L., Fitchett, P., and McCarthy, C. (2019). Risk for occupational stress among US kindergarten teachers. J. Appl. Dev. Psychol. 61, 13-20. doi: 10.1016/j.appdev.2018.07.003

Lambert, R. G., McCarthy, C. J., and Abbott-Shim, M. (2001). Classroom Appraisal of Resources and Demands, School-Age Version. New York, NY: Head Start Quality Research Center.

Lazarus, R. S. (2000). Estrés y Emoción. Manejo e Implicaciones en Nuestra Salud [Stress and Emotion. A New Syntesis. Bilbao: Desclée de Brouwer.

Lazarus, R. S., and Folkman, S. (1986). Estrés y Procesos Cognitivos [Stress and Cognitive Processes]. Barcelona: Martínez Roca.

Leka, S., Griffiths, A., and Cox, T. (2004). La Organización del Trabajo y el Estrés: Estrategias Sistemáticas de Solución de Problemas Para Empleadores, Personal Directivo y Representantes Sindicales [Work Organization and Stress: Systematic Problem-Solving Strategies for Employers, Managers and Union Representatives]. Ginebra: Organización Mundial de la Salud.

Luy-Montejo, C. A., Teves Quispe, J., Rojas Rivera, W., Ramos Quispe, T., Lazo de la Vega Ramos, A. D., and Arias Chávez, D. (2019). Análisis de la producción científica latinoamericana sobre estrés docente (2010-2018) [An analysis of Latin American Scientific Production on Teacher Stress (2010 2018)]. Propósitos y Representaciones 7, 1-6. doi: 10.20511/pyr2019.v7n3.392

MacIntyre, P. D., Gregersen, T., and Mercer, S. (2020). Language teachers' coping strategies during the Covid-19 conversion to online teaching: Correlations with stress, wellbeing and negative emotions. System 94, 1-13. doi: 10.1016/j.system. 2020.102352

Malander, N. (2019). Prevalencia de Burnout en docentes de nivel secundario [Prevalence of burnout in highschool teachers]. Rev. Psicol. 15, 84-99.
Manassero, M. A., Vázquez, A., Ferrer, V. A., Fornés, J., and Fernández, M. C. (2003). Estrés y Burnout en la Enseñanza [Stress and Burnout in Teaching]. Palma de Mallorca: Ediciones UIB.

Marucco, M. A., Flamenco, E., and Ragazzoli, P. N. (2009). Estudio Para Evaluar el Síndrome de Quemarse por el Trabajo (Burnout) y la Calidad de Vida Laboral en Docentes de Educación Primaria Básica (ex EGB 1 y 2) del Programa Integral Para la Igualdad Educativa del Conurbano Bonaerense Sur. Programa de promoción de la Investigación, Formación y Divulgación sobre Riesgos del Trabajo [Study to Evaluate the Burnout Syndrome (Burnout) and the Quality of Working Life in Teachers of Basic Primary Education (former EGB 1 and 2) of the Comprehensive Program for Educational Equality of the South Buenos Aires Suburbs. Program for the Promotion of Research, Training and Disclosure on Occupational Risks. Superintendency of Occupational Hazards]. Buenos Aires: Superintendencia de Riesgos del Trabajo.

Maslach, C. (2009). Comprendiendo el burnout [understanding burnout]. Ciencia y Trabajo 11, 37-43.

Maslach, C., and Jackson, S. E. (1981). The measurement of experienced burnout. J. Organ. Behav. 2, 99-113. doi: 10.1002/job.403002 0205

Maslach, C., and Jackson, S. E. (1986). Maslach Burnout Inventory, 2nd Edn, Palo Alto, CA: Consulting Psychologists Press.

Maslach, C., Schaufeli, W. B., and Leiter, M. P. (2001). Job burnout. Ann. Rev. Psychol. 52, 397-422.

Menghi, M. S. (2015). Recursos Psicosociales y Manejo del Estrés en Docentes [Psychosocial Resources and Stress Management in Teachers]. Buenos Aires: Universidad Católica Argentina Santa María de los Buenos Aires.

Nieva, J. B. (2020). Estrés Ocupacional, Recursos de Afrontamiento y Sintomatología en Docentes de Nivel Inicial de AMBA: Una Mirada Desde la PINE [Occupational Stress, Coping Resources and Symptomatology in AMBA Initial Level Teachers: a View From the PINE]. Tesis doctoral. Buenos Aires: Universidad Argentina de la Empresa.

Oramas Viera, A., Almirall Hernandez, P., and Fernández, I. (2007). Estrés laboral y el síndrome de burnout en docentes venezolanos [Occupational stress and burnout among venezuelan teachers]. Salud de los Trabajadores 15, 71-87.

Oros, L., Vargas Rubilar, N., and Chemisquy, S. (2020). Estresores docentes en tiempos de pandemia: un instrumento para su exploración [Teachers' stressors in times of pandemic: an instrument for their exploration]. Rev. Interam. Psicol. 54:e1421. doi: 10.30849/ripijp.v54i3.1421

Oros, L. B., and Neifert, I. (2006). Construcción y validación de una escala para evaluar indicadores físicos y psicoemocionales de estrés [Construction and validation of a scale to evaluate physical and psycho-emotional indicators of Stress]. Evaluar 6, 1-14. doi: 10.35670/1667-4545.v21.n1.32829

Othman, Z., and Sivasubramaniam, V. (2019). Depression, anxiety, and stress among secondary school teachers in Klang, Malaysia. Intern. Med. J. 26, 71-74.

Peiró, J. M., and Salvador, A. (1993). Control del Estrés Laboral [Control of Work Stress]. Madrid: EUDEMA.

Ramos, J., Montalbán, M., and Bravo, M. (1997). "Burnout: estrés en las organizaciones: concepto, consecuencias y control [Burnout: stress in organizations: concept, consequences and control]," in Estrés y Salud, ed. I. Hombrados (Valencia: Promolibro), 171-212.

Ratto Dattoli, A., García Pérez, R. C., Silva, M. I., and González, M. (2015). El síndrome de quemarse por el trabajo y factores psicosociales en docentes de primaria de la ciudad de Montevideo [burnout syndrome and psychosocial factors in primary school teachers in montevideo]. Ciencias Psicol. 9, 273-281.

Rionda Arjona, A., and Mares Cárdenas, M. G. (2011). Burnout en profesores de primaria y su desempeño laboral [Burnout among elementary school teachers and their work performance]. Rev. Latinoam. Med. Conductual 2, 43-50.

Salanova, M., Llorens, S., and García-Renedo, M. (2003). ¿Por qué se están quemando los profesores? [Why are teachers burning?]. Prevención, Trabajo y Salud 28, 16-20.

Sánchez Mendiola, M., Martínez Hernández, A. M. D. P., Torres Carrasco, R., Agüero Servín, M., Hernández Romo, A. K., Benavidez Lara, M., et al. (2020). Retos educativos durante la pandemia de COVID-19: una encuesta a profesores de la UNAM [Educational challenges during the covid-19 pandemic: a teachers' survey at unam]. Rev. Digital Univer. 21, 1-24. doi: 10.22201/codeic.16076079e. 2020.v21n3.a12 
Santoro, S. (2020). Coronavirus: la Escuela en Cuarentena [Coronavirus: the School in Quarantine]. Página 12. Available online at: https://www.pagina12.com.ar/ 260580-coronavirus-la-escuela-en-cuarentena (accessed December 3, 2020).

Schaufeli, W. B. (2003). Past performance and future perspectives of burnout research. J. Indust. Psychol. 29, 1-15. doi: 10.4102/sajip.v29i4.127

Schaufeli, W. B., and Buunk, B. P. (2002). "Burnout: an overview of 25 years of research and theorizing," in The Handbook of Work and Health Psychology, 2nd Edn. eds M. J. Schabracq, J. A. M. Winnubst, and C. L. Cooper (Chichester: John Wiley \& Sons), 383-425.

Schaufeli, W. B., and Enzmann, D. (1998). The Burnout Companion to Study and Practice: A Critical Analysis. Milton Park: Taylor \& Francis.

Schaufeli, W. B., Leiter, M. P., and Maslach, C. (2009). Burnout: 35 years of research and practice. Career Dev. Intern. 14, 204-220. doi: 10.1108/1362043091096 6406

Seijas-Solano, D. E. (2019). Riesgos psicosociales, estrés laboral y síndrome burnout en trabajadores universitarios de una escuela de bioanálisis [Psychosocial risks, occupational stress and burnout syndrome in university workers from a Bioanalysis School]. Rev. Salud Pública 21, 102-108.

Seisdedos, N. (1997). MBI. Inventario «Burnout» de Maslach: Manual. Madrid: TEA.

Sindicato Argentino de Docentes Particulares (2020). Encuesta Nacional “Contanos Para Cuidarte" [National Survey "Tell us to Take Care of You"]. Available online at: https://sadop.net/wp-content/uploads/2020/05/Encuesta-Contanos-paracuidarte-An\%C3\%A1lisis-de-Resultados.pdf (accessed December 3, 2020).

Sindicato Unificado de Trabajadores de la Educación de Buenos Aires (2020). Encuesta Provincial de Trabajo Docente en Contexto de Aislamiento [Provincial Survey of Teacher Work in a Context of Isolation]. Available online at: https: //www.suteba.org.ar/download/encuesta-provincial-de-trabajo-docente-encontexto-de-aislamiento-se-presentaron-los-resultados-84841.pdf (accessed December 3, 2020).

Teles, R., Valle, A., Rodríguez, S., Piñeiro, I., and Regueiro, B. (2020). Perceived stress and indicators of burnout in teachers at Portuguese higher education institutions (HEI). Intern. J. Environ. Res. Public Health 17:3248. doi: 10.3390/ ijerph 17093248

Urquidi Treviño, L. E., and Rodríguez Jiménez, J. R. (2010). Estrés en profesorado universitario mexicano [Stress in Mexican university professoriate]. Rev. Electrón. Actualidades Invest. Educ. 10, 1-21. doi: 10.15517/aie.v10i2.10111

Vallejos, S. (2020). Coronavirus en la Argentina. Jornadas Interminables y Mucho Estrés, así es el día a día de los Maestros a un mes y Medio de la Cuarentena [Coronavirus in Argentina. Endless Days and a Lot of Stress, this is the Day to Day of Teachers a Month and a Half After Quarantine]. La Nación. Available online at: https:/www.lanacion.com.ar/sociedad/coronavirus-argentinajornadas-interminables-mucho-estres-asi-nid2361011 (accessed December 3, 2020).

Vandenberghe, R., and Huberman, A. M. (1999). Understanding and Preventing Teacher Burnout: A Sourcebook of International Research and Practice. Cambridge: Cambridge University Press.

Conflict of Interest: The authors declare that the research was conducted in the absence of any commercial or financial relationships that could be construed as a potential conflict of interest.

Publisher's Note: All claims expressed in this article are solely those of the authors and do not necessarily represent those of their affiliated organizations, or those of the publisher, the editors and the reviewers. Any product that may be evaluated in this article, or claim that may be made by its manufacturer, is not guaranteed or endorsed by the publisher.

Copyright (C) 2021 Vargas Rubilar and Oros. This is an open-access article distributed under the terms of the Creative Commons Attribution License (CC BY). The use, distribution or reproduction in other forums is permitted, provided the original author(s) and the copyright owner(s) are credited and that the original publication in this journal is cited, in accordance with accepted academic practice. No use, distribution or reproduction is permitted which does not comply with these terms. 